\title{
Governance Analysis of Two Historical MPAs in Northern Peru: Isla Lobos de Tierra and Isla Lobos de Afuera
}

\section{AUTHORS}

Daniela Laínez del Pozo, Department of Geography, University College London, United Kingdom Peter JS jones, Department of Geography, University College London, United Kingdom

*Corresponding author: daniela.pozo.14@ucl.ac.uk

\section{HIGHLIGHTS}

- History can play an integral part in protected area governance

- Historical governance and social relationships help conserve the Lobos Islands

- Informality and poor governance structures perpetuate marine degradation

- Combined top-down/bottom-up approaches and a diligent state, key to good governance

\begin{abstract}
Isla Lobos de Tierra and Isla Lobos de Afuera are two MPAs that show the importance of history in governance. In 2009 they were designated among the Guano Islands, Islets and Capes Reserve System for wildlife conservation and sustainability, after being protected for hundreds of years to manage guano. Since their designation, governance changed on paper, but not de facto. The major driver undermining conservation is fishing, which is enhanced by pressures of the global seafood market and informality (the predominant way of thinking and acting in Peru, transgressive of order and disrespectful of values, norms and institutions). Fish productivity in the Humboldt Current Large Marine Ecosystem is the source of wildlife bounty around these small islands. Few incentives have been initiated to protect it and none looks at directly regulating fisheries. An obstacle is that the Parks Service has no authority to manage marine species. Management effectiveness requires improving cross-jurisdictional coordination with the Vice-Ministry of Fisheries, the Maritime Authority and other relevant entities to develop an integral plan where they all convene on working towards conserving these MPAs. Success will rely on an improved and diligent state participation that deeply understands the social complexities of these environments in order to address informality and potential equity issues. Despite the minimal intervention, the land ecosystem and its species remain relatively protected due to a governance legacy of strict enforcement and fraternal relationships between guardians and artisanal fishers, which highlights the importance of recognising history in conservation.
\end{abstract}

\section{KEYWORDS}

Governance analysis; Marine protected areas; MPA; History; Peru

This is the authors' version of the final accepted Marine Policy manuscript. Elsevier (C 2020. This manuscript version is made available under the CC-BY-NC-ND 4.0 license. https://doi.org/10.1016/j.marpol.2020.104096 


\section{INTRODUCTION}

The islands along the coast of Peru are historical refuges for marine wildlife. Strong upwelling currents make marine life abound. Seabirds thrive, painting the islands white with their worldfamous guano, considered one of the best organic fertilisers ever produced [1]. Three bird species are mainly responsible for guano, the guanay cormorant (Phalacrocorax bougainvillii), the Peruvian booby (Sula variegata) and the Peruvian pelican (Pelecanus thagus). Because of their guano producing capabilities, these islands are locally named guaneras and were strictly protected for hundreds of years. In 2009 they were officially designated as the Guano Islands, Islets and Capes Reserve System for biodiversity conservation and sustainable resource use, opening them to a more diverse governance framework. The reserve system comprises $1,408 \mathrm{~km}^{2}$ of land and sea state-owned territory, distributed in 25 MPAs along the 3,080 km coastline (Fig. 1).

Two of these islands make the case to demonstrate the integral role that history can play in the governance of protected areas; these are Isla Lobos de Tierra Reserve (ILTR) and Isla Lobos de Afuera Reserve (ILAR). Together they are known as the Lobos Islands for their relative proximity and shared history, and they are the northernmost and most remote offshore units of the reserve system.

This paper analyses the governance of ILTR and ILAR, developed in full in a related PhD thesis [2] using the MPA governance framework (MPAG) $[3,4]$ (details in the introduction and discussion papers of this special section of Marine Policy). Research was conducted from 2015-2019 under a case study design using ethnographic methods (i.e. participant observation, semi-structured interviews with actors from different sectors ( $n=48)$ and document analysis). It included 15 months of regular on-site fieldwork at ILTR and its outside spaces of influence. ILAR appeared as a satellite case study after the preliminary analysis.

The Lobos Islands are of scientific interest for their biodiversity and biogeographical importance. They occur in the ecotone between the Humboldt Current and the Tropical Eastern Pacific large marine ecosystems, opposite to the coasts of the regions of Piura and Lambayeque (Fig. 1) [5,6]. Due to the strong influence of the Southern Equatorial Current, they are highly vulnerable to ENSO and climate change. These MPAs are also on the migratory route of humpback whales (Megaptera novaeangliae), which concentrate around them during their breeding season, June to September [7]. Their major economic activity and driver of environmental change is fishing. It used to be guano collection, but this was suspended in the 1990s.

Laínez del Pozo, D. and Peter J.S. Jones (in press) Governance analysis of two historical MPAs in northern Peru: Isla Lobos de Tierra and Isla Lobos de Afuera. Marine Policy 104096 https://doi.org/10.1016/j.marpol.2020.104096 One of 20 papers in a special section of 28 case studies on MPA Governance 
ILTR is recognised for the largest natural seedbank of Peruvian scallops (Argopecten purpuratus) and the largest breeding colonies of blue-footed booby (Sula nebouxii) and Peruvian pelican (Pelecanus thagus) in the world [8,9]. It is the largest MPA of the guaneras reserve system $\left(182.8 \mathrm{~km}^{2}\right)$.

ILAR is much smaller $\left(82.6 \mathrm{~km}^{2}\right)$ but it is especially attractive to fishers looking for big, high quality rockfish and octopus due to its remoteness and rocky habitats. It hosts the third largest colony of South-American sea lions (Otaria flavescens) and the largest breeding colony of Nazca boobies (Sula granti) in Peru [9].

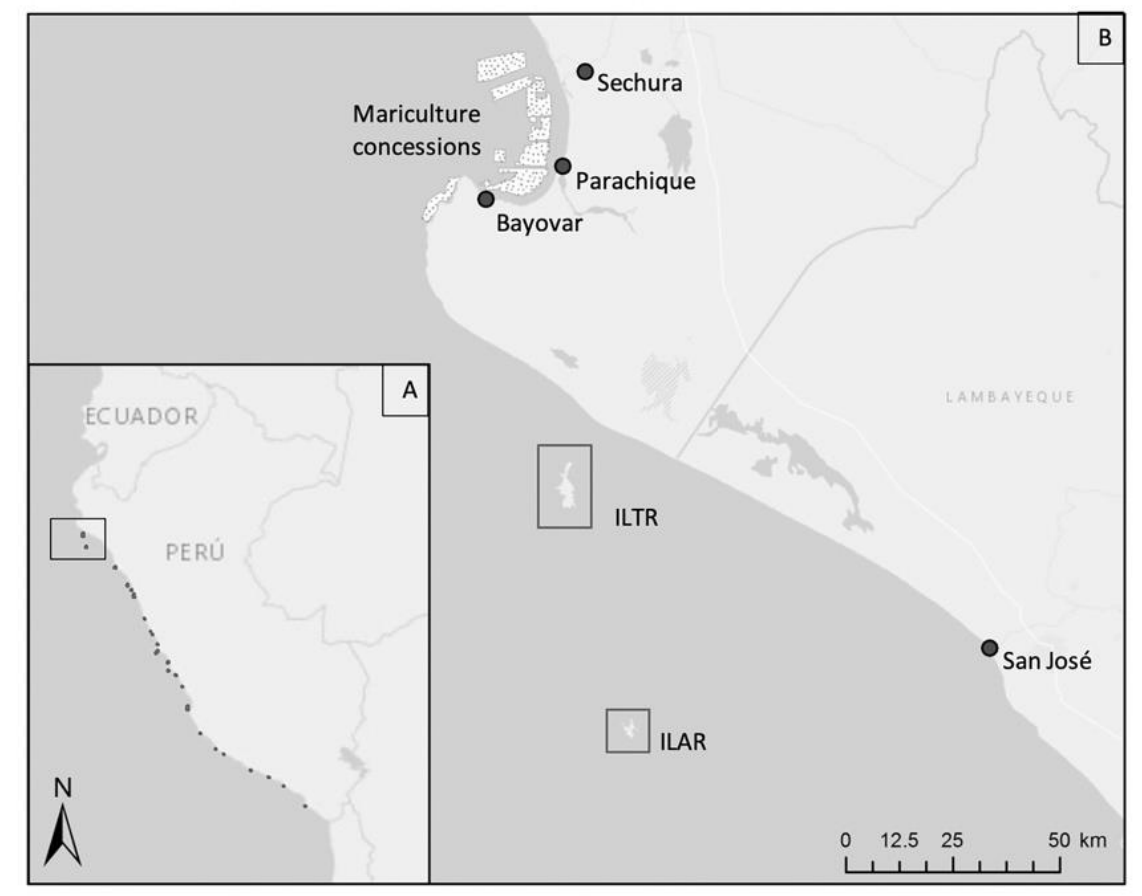

Figure 1. (A) Guano Islands, Islets and Capes Reserve System. (B) Isla Lobos de Tierra Reserve, Isla Lobos de Afuera Reserve and the mariculture concessions in the bay of Sechura

\section{CONTEXT}

\subsection{Historical background}

For early Peruvians of the Moche culture, ILTR and ILAR were sacred (100-700 AD) [10,11]. During the later Inca period they were protected under pain of death together with all other islands [12]. Protection worked similar to community-based protected areas [13], and property rights were assigned to local communities for their benefit (Fig. 2) [12]. The larger aim was to protect the birds 
and ecosystem that supported the Inca agricultural system in the Andes. This bond between the islands and people from the mountains was part of a tradition of vertical ecological complementarity that still remains [14].

With the Spanish invasion in 1532 (Fig. 2), most of the native coastal populations and traditions were eradicated, interrupting the protection of these islands. Native people were abused and marginalised, turning to transgression as their legitimate defence [15], an expression that continues to be the predominant way of thinking and acting in Peru. This disrespect of values, norms and institutions, is also known as informality.

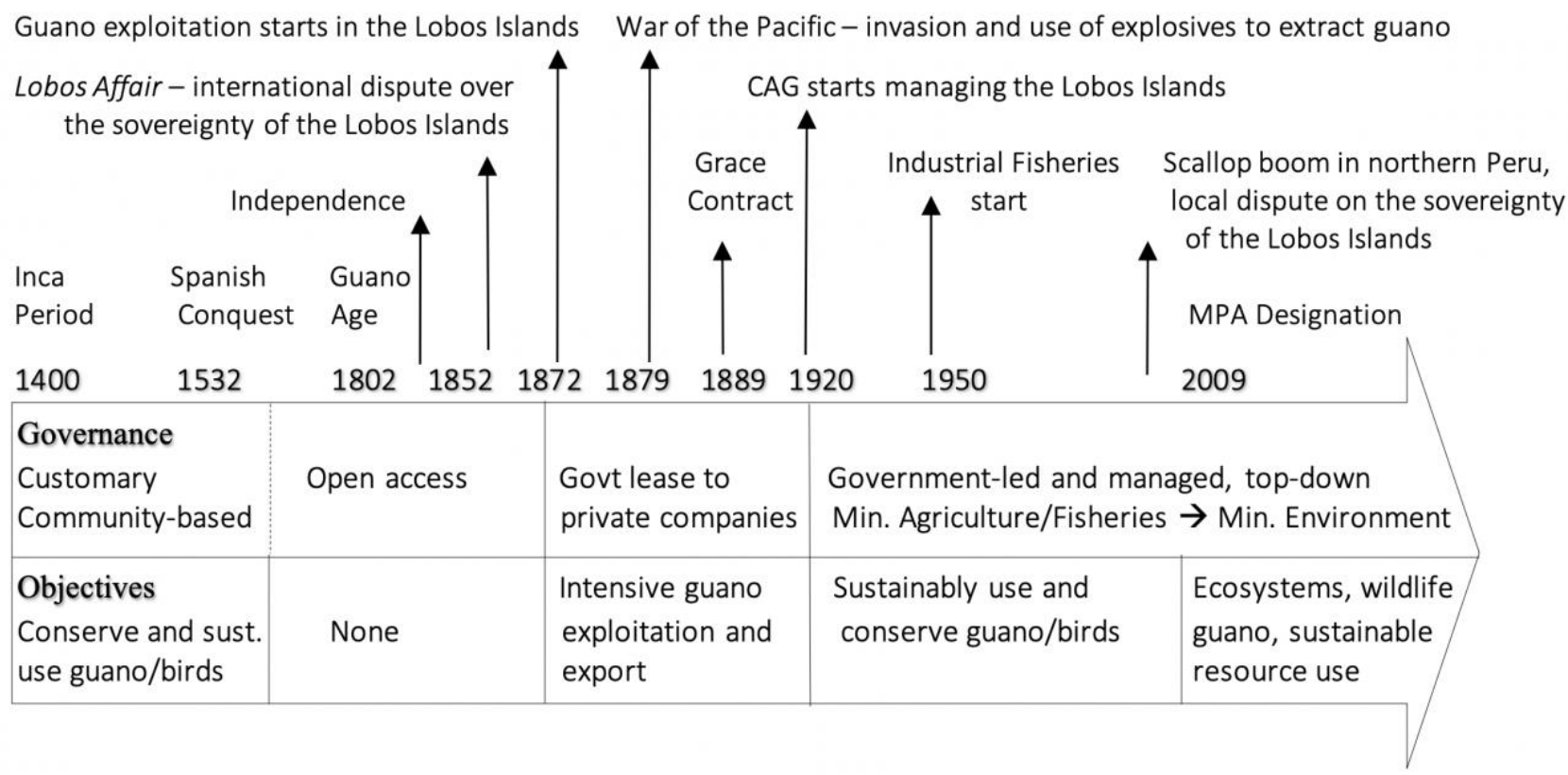

Figure 2. Governance Trajectory of ILTR and ILAR [1,12,16-21]

What happened to the Lobos Islands after the Spanish invasion seems unknown until the Guano Age (1802-1884), when guano became a commodity of global importance. In 1852 the Lobos Islands were rediscovered as the last and largest guano deposits in the world, leading to The Lobos Affair [16], a chapter that marked the start of a race for resource use and territorial conflict in these islands. The USA, Great Britain and France declared these islands res nullius to gain access. A year later, after a rigorous defence, Peru demonstrated their historical use, so they were recognised as Peruvian. Commercial guano exploitation started after that in 1872 [17].

During the War of the Pacific, the Lobos Islands played a key role. In 1879 they were invaded and sacked using explosives. Being the largest guano deposits, they were negotiated in the Ancón Peace Treaty that put an end to the war [22], and in 1889 they were again negotiated in the Grace

Laínez del Pozo, D. and Peter J.S. Jones (in press) Governance analysis of two historical MPAs in northern Peru: Isla Lobos de Tierra and Isla Lobos de Afuera. Marine Policy 104096 https://doi.org/10.1016/j.marpol.2020.104096 One of 20 papers in a special section of 28 case studies on MPA Governance 
Contract to pay for Peru's war debt [16]. After the war, only 4 million guano birds remained from the 36 million estimated in 1851 in the country (Fig 3) [18].

Guano was the most important resource, so the government created the state-owned Company for the Administration of Guano (CAG), to restore and manage the guano deposits. The guaneras were put under CAG management in 1909, except for the Lobos Islands which were included later when the Grace Contract ended with WW1. The CAG established strong protection measures $[1,28]$. Seasonal fishers were evicted, and fishing was pushed back $2 \mathrm{~nm}$ from the shore to minimise impacts. Guano labourers worked under strict vigilance. Exploitation occurred every 5 to 10 years per site to give the birds and guano enough time to accumulate. The rest of the time there were no people, except for one or two island guardians armed with shotguns to control human access.

Guardians were permanently installed in the islands. Following an ancestral tradition of vertical ecological complementarity [14], they came from the Andes to gain access to guano for their farmlands. Until today, many guano workers come from the Andes and guano production is legally prioritised for small farmers in the rural Andes [29]. Many guardians inherit the role from their relatives, thus the strong fraternal and respectful relationships with traditional fishers [1 p.188].

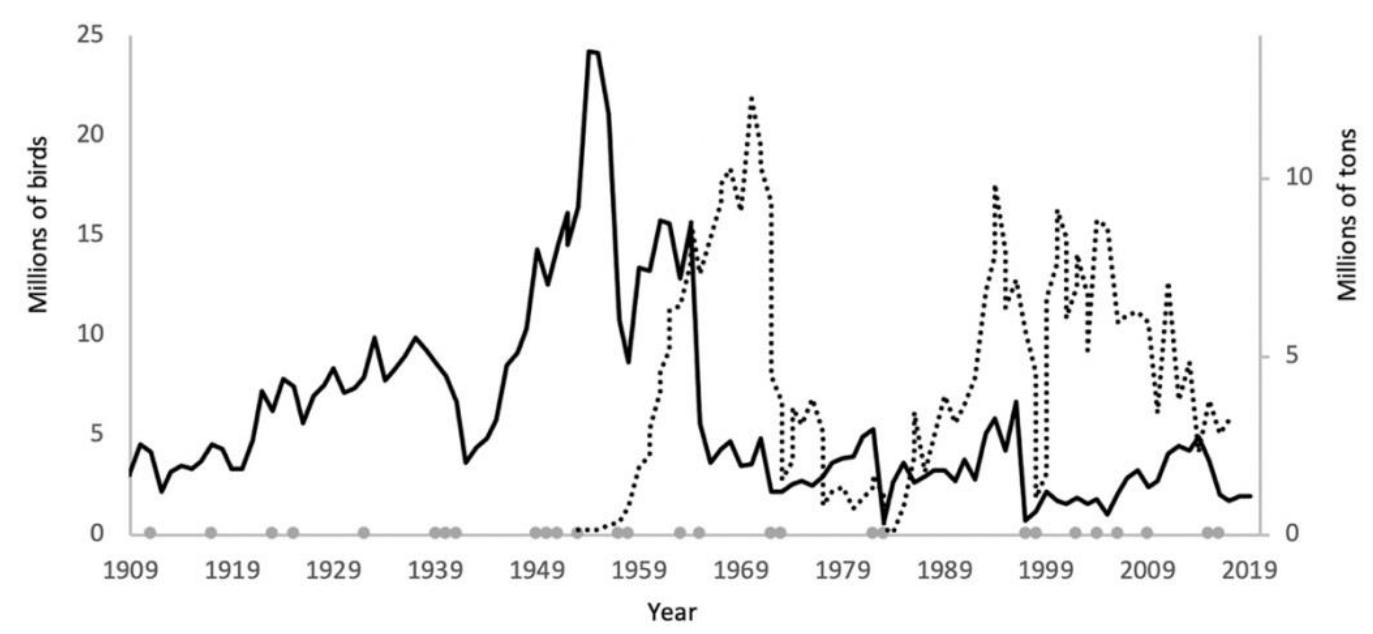

Figure 3. Estimated guano bird population numbers (black line) vs landings of Peruvian anchovy (dotted line). Grey circles on the X-axis indicate El Niño southern oscillation years. (Data sources derived from [2327] and unpublished survey data from AGRORURAL)

At the Lobos Islands, traditional fishers had special treatment from the CAG, probably due to their remoteness. They had exceptional authorisation to come close to shore during guano extraction seasons, without disturbing the birds. They were allowed to land, and they were also conceded special areas to salt their fish under strict guidelines [30].

Laínez del Pozo, D. and Peter J.S. Jones (in press) Governance analysis of two historical MPAs in northern Peru: Isla Lobos de Tierra and Isla Lobos de Afuera. Marine Policy 104096 https://doi.org/10.1016/j.marpol.2020.104096 One of 20 papers in a special section of 28 case studies on MPA Governance 
The strict top-down governance by the CAG recovered Peru's guano bird populations in the 1950s (Fig. 3), but success did not last long. Industrial fishing of Peruvian anchoveta grew quickly, extracting millions of tonnes of anchovies. When El Niño hit the coast of Peru in 1965, 1972/73, 1982/83 and 1997/98, the birds had lost their ability to recover and populations dropped again. Birds and guano collapsed and now fluctuate between 1-5 million in the country.

Governance of the guaneras failed because it was entirely dependent on the exploitation of guano. By 1963 industrial fisheries displaced guano exploitation as the largest economic activity in the ocean and the CAG ceased to exist. The guano industry experienced an economic crisis. Management shifted from one agency to another in the Ministries of Agriculture and Fisheries. Protection became weaker with no economic incentive for it to continue. Some breeding colonies were abandoned and many guaneras were left unprotected [23]. This raised concern of local NGOs who formed the BIOMAR consortium to push forward the creation of the Guano Islands, Islets and Capes Reserve System.

\subsection{Contemporary background}

The state declared the need to designate the guaneras reserve system in 1995 [31]. It created the Special Project to Promote the Use of Seabird Fertilizer - PROABAONOS, to sustainably manage the guaneras and restore bird populations [32]. The first action was to ban all motorised activity within 2nm from the shores of the guaneras in 2000 [33] and then ban any kind of navigation and extractive activities within 200m from shore in 2001 [34]. In 2008 the Rural Agrarian Development Programme AGRORURAL merged with PROABONOS, taking over management of the guaneras.

While the official designation of the reserves was being discussed in the early 2000s, the scallop boom appeared as a new driver and is now the most important fishery in ILTR. Scallop extraction began in 1982 in Independence Bay, southern Peru, as the most productive seedbank but by 2001 it became overexploited. The seedbank in the bay of Sechura replaced it but it soon declined in 2003 and divers moved to ILTR. Speculative traders installed illegal sea farms and campsites in ILTR for some years, later removed by the government. Now divers extract scallops from ILTR and farm them in mariculture concessions in the bay [35]. However, whenever the seedbank booms, divers take illegal possession of the sea floor again. This boom triggered exponential migration and unregulated urbanisation in the nearest towns, Sechura and Parachique (Fig. 1), changing the social configuration, livelihoods and access of traditional handline fishers to their fishing grounds $[36,37]$.

Laínez del Pozo, D. and Peter J.S. Jones (in press) Governance analysis of two historical MPAs in northern Peru: Isla Lobos de Tierra and Isla Lobos de Afuera. Marine Policy 104096 https://doi.org/10.1016/j.marpol.2020.104096 One of 20 papers in a special section of 28 case studies on MPA Governance 
Encouraged by this boom, in 2004 both the Regional Government of Piura and the Regional Government of Lambayeque set ordinances to declare their individual sovereignty over ILTR, given it is opposite to the coasts of both regions (Fig. 1). Each delineated their own management plans for ILTR. The dispute was taken to the Constitutional Tribunal that ruled these islands should be managed at the national level [38]. Scallop extraction was banned in ILTR in 2006, but still remains the most important source of spat for mariculture [20].

In 2009 the Guano Islands, Islets and Capes Reserve System was finally declared. Since then, biodiversity conservation is the main purpose for their protection. The Lobos Islands are part of this set. They are uninhabited and the most remote north and offshore, yet fishers visit them all year round, dependent on fish availability and the demands of the global seafood market. Only 24 guardians from AGRORURAL live on each site. In ILAR there are also two staff members from the Directorate of Hydrography and Navigation looking after the lighthouse. The coast opposite to the islands is also uninhabited (Fig. 1). The closest towns are far from big cities and less developed than the national average (Table 1). ILTR is $100 \mathrm{~km}$ away from the nearest port, Bayovar, and 130 $\mathrm{km}$ away from the nearest town, Sechura. ILAR is $93 \mathrm{~km}$ away from the nearest town and port, San José. Fishers who embark from the ports of Bayovar or Parachique navigate about $12 \mathrm{~h}$ to reach ILTR and an extra 5-6 $\mathrm{h}$ to reach ILAR. Some boats navigate directly from San José to ILAR, accepting the risk of breaking waves on the passgae. Bayovar is the most popular port of embarkation, but is an informal landing site lacking basic services, infrastructure and licenses: "It has 40 illegal fish processing plants and clandestine petrol stations (...) the area swarms crime: bodyguards, hired killers and security charges by criminals occur alongside prostitution and the proliferation of bars' [40].

Table 1. Main development metrics and ranks in Peru

\begin{tabular}{|l|l|l|l|}
\hline GDP Per Capita & $\begin{array}{l}\text { US\$ 13,300 } \\
(2017,120 / 229)\end{array}$ & State Capacity & $\begin{array}{l}-0.12 \text { (average } \% \\
\text { rank 46.56, 2017) }\end{array}$ \\
\hline GDP Growth Rate & $4 \%(2018)$ & $\begin{array}{l}\text { Human Development } \\
\text { Index (HDI) }\end{array}$ & $\begin{array}{l}0.759(82 / 187, \\
2019)\end{array}$ \\
\hline
\end{tabular}

For sacred and utilitarian purposes, the conception of these spaces has been attached to long periods of strict protection and resource extraction, which influence the way drivers, conflicts, governance and conservation effectiveness are expressed today.

Laínez del Pozo, D. and Peter J.S. Jones (in press) Governance analysis of two historical MPAs in northern Peru: Isla Lobos de Tierra and Isla Lobos de Afuera. Marine Policy 104096 https://doi.org/10.1016/j.marpol.2020.104096 One of 20 papers in a special section of 28 case studies on MPA Governance 


\section{OBJECTIVES}

The general goals of the whole reserve system are to: (a) conserve the insular and marine ecosystems, (b) develop sustainable activities, and (c) promote actor participation in MPA management. Given ILTR and ILAR are similar in some ways, they share similar specific objectives (Table 2).

Table 2. Conservation and operational objectives of Isla Lobos de Tierra ILTR and Isla Lobos de Afuera ILAR

Conservation objectives Operational objectives

1. Maintain the conservation status of the:

- Insular and marine ecosystems of the MPA

- Intertidal and subtidal ecosystems

(baselines for these objectives are not yet established)

2. Maintain the minimum population range of the following species for the whole reserve system, under normal environmental conditions without ENSO:

- Guano birds: Peruvian pelican Pelecanus thagus, guanay cormorant Phalacrocorax bougainvillii, blue-footed booby Sula nebouxii and Peruvian booby Sula variegata (2-6 million individuals)

- South American sea lions Otaria flavescens (17,000-32,000 individuals)

3. Maintain the presence and distribution of the following species:

- Peruvian rock seabass Paralabrax humeralis

- Peruvian grunt Anisotremus scapularis (only ILAR)

- Sea snail Stramonita chocolata

- Peruvian scallops Argopecten purpuratus

- Octopus Octopus mimus

- Kelp forests (only ILTR)

- Black sea turtle Chelonia mydas (only ILTR)
1. Ensure $20 \%$ of the fishers identified as actors are formal and benefit from the MPAs

2. Ensure fishers have higher incomes from marine resources compared to the baseline in 2016

3. Achieve a conservation agreement between fishers and the Parks Service (SERNANP) in ILTR by 2020

4. Promote income from guano exploitation

5. Concede two concession rights for tourism in ILTR by 2020

6. By 2020, increase the number of visitors to ILTR by $15 \%$ as compared to 2015

7. By 2020, increase the economic returns from tourism in ILTR by $10 \%$ as compared to 2015

8. Increase by $20 \%$ the number of actors involved in the management of the MPAs by 2020

9. Improve the score of the 'participatory radar' (management tool to assess actor participation) of the MPA network to values above 2015 levels (score of 28) 


\section{DRIVERS/CONFLICTS}

4.1 Fishing. Fishing concentrates within the $2 \mathrm{~nm}$ polygons that demarcate these reserves [41], not respecting the navigation and fishing regulations (Table 4) of these islands. It often occurs in vulnerable and prohibited spots (i.e. scallop seedbanks, near seabird and sea lion colonies), catching banned species (e.g. Peruvian scallops, seahorses) or individuals below minimum legal landing sizes. Some fishers also poach sea turtles, seabirds and their eggs [42]. Eight main types of fishing coexist in these MPAs (Table 3), noting these categories are not rigid and some fishers jump from one type of fishing to the other.

Table 3. Fishing types in ILTR and ILAR

\begin{tabular}{|c|c|c|c|c|c|c|c|c|}
\hline \multirow{3}{*}{ Characteristics } & \multicolumn{8}{|c|}{ Fishing type } \\
\hline & \multirow[b]{2}{*}{ Handline } & \multirow[b]{2}{*}{ Gill net } & \multicolumn{4}{|c|}{ Hookah diving } & \multirow{2}{*}{$\begin{array}{c}\text { Small purse- } \\
\text { seiners }\end{array}$} & \multirow{2}{*}{$\begin{array}{l}\text { Squid } \\
\text { fishers }\end{array}$} \\
\hline & & & $\begin{array}{c}\text { for fish \& } \\
\text { octopus }\end{array}$ & $\begin{array}{c}\text { with purse seine } \\
\text { nets }\end{array}$ & $\begin{array}{c}\text { for } \\
\text { scallops }\end{array}$ & $\begin{array}{c}\text { with gill } \\
\text { nets }\end{array}$ & & \\
\hline Date of origin & Pre-Columbian & Pre-Columbian & Mid 1970s & Mid 1990s & 2003 & 2016 & $1960 s$ & 2000 \\
\hline \multicolumn{9}{|l|}{ Main gear } \\
\hline - Hooks & $\mathrm{X}$ & & & & & & & $x$ \\
\hline - Lines & $x$ & & & & & & & \\
\hline - Gill net & & $\varnothing 3-6 "$ & & & & $\varnothing 2.5-4 "$ & & \\
\hline - Air compressor & & & $x$ & $x$ & $x$ & $x$ & & \\
\hline - Mesh bag & & & $x$ & & $x$ & & & \\
\hline $\begin{array}{l}\text { - Spear, trident, } \\
\text { hook }\end{array}$ & & & $x$ & & & & & \\
\hline - Purse-seine net & & & & $\varnothing 1-1.5^{\prime \prime}$ & & & $\begin{array}{c}\varnothing 1-1.5^{\prime \prime} \\
\text { (mechanised) }\end{array}$ & \\
\hline - Squid jig & & & & & & & & $x$ \\
\hline - GPS Navigation & A few & A few & $x$ & $x$ & $\mathrm{X}$ & $x$ & $x$ & $x$ \\
\hline - Echosounder & & & & $x$ & & $x$ & $x$ & $x$ \\
\hline - Radio & & & & & & & $x$ & $x$ \\
\hline Storage capacity $(t)$ & $1-8$ & $3-8$ & $7-18$ & $7-18$ & $7-18$ & $7-18$ & $10-32.6$ & $3-32.6$ \\
\hline \multicolumn{9}{|l|}{ Number of boats } \\
\hline - ILTR & $10-25$ & $6-10$ & $3-10$ & $\cong 10$ & $70-500$ & $\cong 10$ & $60-80$ & $>100$ \\
\hline - ILAR & $10-15$ & $6-8$ & $4-6$ & $3-10$ & 0 & $\cong 10$ & $60-80$ & $>100$ \\
\hline № fishers per boat & 6 & 4 & $4-6$ & 6 & 6 & 6 & 10 & $5-12$ \\
\hline Species & $\begin{array}{l}\text { Rockfish and } \\
\text { small pelagics, } \\
\text { mainly } \\
\text { Peruvian rock } \\
\text { seabass, small } \\
\text { eastern Pacific } \\
\text { bonito and } \\
\text { mackerel }\end{array}$ & $\begin{array}{l}\text { Small sharks, } \\
\text { rays and small } \\
\text { pelagics }\end{array}$ & $\begin{array}{l}\text { Octopus, } \\
\text { rockfish } \\
\text { and snails }\end{array}$ & $\begin{array}{l}\text { Rockfish and } \\
\text { small pelagics }\end{array}$ & $\begin{array}{l}\text { Peruvian } \\
\text { scallops }\end{array}$ & $\begin{array}{l}\text { Rockfish } \\
\text { and small } \\
\text { pelagics }\end{array}$ & $\begin{array}{l}\text { Small } \\
\text { pelagics, } \\
\text { mainly } \\
\text { mackerel, } \\
\text { small eastern } \\
\text { Pacific } \\
\text { bonito, } \\
\text { Peruvian } \\
\text { weakfish and } \\
\text { stripped } \\
\text { mullet }\end{array}$ & $\begin{array}{l}\text { Dosidicus } \\
\text { gigas }\end{array}$ \\
\hline
\end{tabular}

Laínez del Pozo, D. and Peter J.S. Jones (in press) Governance analysis of two historical MPAs in northern Peru: Isla Lobos de Tierra and Isla Lobos de Afuera. Marine Policy 104096 https://doi.org/10.1016/j.marpol.2020.104096 One of 20 papers in a special section of 28 case studies on MPA Governance 
The most prominent driver of overexploitation in ILTR is the illegal extraction of spat by divers. It supplies $75-90 \%$ of the spat used for mariculture in the bay of Sechura [43], which reached USD 150 million in exports in 2016 [44] and represents about 80\% of total scallop production in Peru [20]. During scallop seasons divers come from across the country and all local divers turn to spat extraction. When there is no spat, local divers go back to other diving activities.

Diving using bottom purse-seine nets is another illegal and high-impact activity in ILTR. It is a hybrid technique, divers scare fish into bottom trawling nets and enclose them like in purse seine fishing [45]. Performed by divers, it is limited to shallow areas. The technique is banned because of its negative impact: low selectivity, high extraction of juveniles and great fishing power [46]. This fishing became extensive with the massive migration of divers who had no traditional ecological knowledge of the sea and adopted this type of diving. In ILAR it was eliminated ten years ago when fishers organised themselves and managed to scare these divers away with the support of small-scale purse seiners. In ILTR the issue is more difficult to battle because the island is 2.2 times bigger and closer to the mainland, making trespassers more prone to coming back despite the risk of being chased away. These divers are in conflict with all other fishers because they impact the sustainability of marine resources and local livelihoods. This has created a clash of cultures and political uncertainty, since hookah divers are mainly migrants and are displacing local artisanal fishers.

In ILAR, diving with gill nets emerged as a modified practice after a Ministerial Resolution banned the technique of enclosing fish with bottom purse-seine nets [46]. It is a modification that makes diving with nets legally ambiguous to perpetuate a highly impactful practice. They extend gill nets on the ocean floor and surround and scare fish to get them tangled in the nets. Untangling fish requires great effort, hence this practice has not become that extensive. Diving dependent, it also catches high numbers of juvenile fish that have not reached their reproductive age. Smallscale purse-seining is probably the most impactful fishing activity in ILAR after diving with gill nets, though it was the organisation of this fleet that chased away divers using bottom purseseine nets.

Jumbo squid fishing, though highly variable and random, is worth noting because it is the second largest capture fishery in Peru. When available, fishers come from all along the coast and local fishers turn to it, sometimes fishing very close to shore. It is recorded in ILAR [41] and fishers' manifests indicate it occurs in the proximity of ILTR, where it is not rare to find stranded carcasses of sea lions with squid jigs in their mouths.

Laínez del Pozo, D. and Peter J.S. Jones (in press) Governance analysis of two historical MPAs in northern Peru: Isla Lobos de Tierra and Isla Lobos de Afuera. Marine Policy 104096 https://doi.org/10.1016/j.marpol.2020.104096 One of 20 papers in a special section of 28 case studies on MPA Governance 
The predominant informality in Peru, which has historical roots, is a factor that exacerbates fishing conflicts at every level, not allowing fishing to be regulated and made sustainable. For example, entrepreneurs mask their industrial activity as if it was artisanal for its regulatory benefits, owning large fleets of 'small-scale' 32-ton artisanal vessels to avoid being considered industrial. This is supported by an ambiguous General Fishing Law that classifies them as artisanal along with smaller handline fishers who catch $<10 \mathrm{~kg}$ of fish a day. They obtain the same state benefits though differences in their profits and pressure on the ecosystem are enormous [47]. The first $5 \mathrm{~nm}$ are reserved for these artisanal fishers, who can work all along the coast without regional restrictions, limitations on catches, fleet size or payment of fees. This allows interloping fishers to migrate across the country whenever a marine resource booms in a specific location, encouraging unregulated fishing and overexploitation. Another example is concession rights for mariculture in the bay of Sechura. By law these should be exclusively awarded to artisanal fishing associations, but there are many ghost associations where members are businesspeople, and there are also fisher-owned concessions that are rented to the larger industry under the table. This informality starts a chain of cheap labour and promotes a culture of poor fishing and diving conditions that in ILTR has led to fatality rates of 40-50 per year according to state officers; leaving no incentive for fishers to formalise, follow regulations, or get licenses, navigation permits, diving training etc. It encourages illegal behaviour and attracts fishers from illegal backgrounds, many prosecuted by law, generating a vicious circle where environmental sustainability and biodiversity conservation become an obstacle. Remote and resource-rich areas like these are the perfect spots for the surge of these corrupted environments.

4.2 Impacts related to human presence, which are exacerbated by a lack of mitigation measures. There is no waste management plan [42], so visitors spill sewage and throw organic and solid waste to the ocean in amounts that accumulate on the beaches, where seabirds construct nests using this litter [6]. There is also sound pollution from hookah divers [7], reported to interrupt humpback whales in their breeding and migrating season.

4.3 Invasive species. Introduced unintendedly probably over 100 years ago, many threaten seabird populations e.g. feral cats (ILTR) and rats (ILAR) [6,9,42].

4.4 Oil exploitation. This can be considered a latent conflict, and even if its impacts have not been assessed, the risk of an oil spill in the adjacent oil development blocks [48] could impact the ecosystem.

Laínez del Pozo, D. and Peter J.S. Jones (in press) Governance analysis of two historical MPAs in northern Peru: Isla Lobos de Tierra and Isla Lobos de Afuera. Marine Policy 104096 https://doi.org/10.1016/j.marpol.2020.104096 One of 20 papers in a special section of 28 case studies on MPA Governance 
4.5 Guano extraction. This was the greatest driver of degradation in the past due to direct habitat loss and poaching [49,50], but harvesting was suspended from ILAR in 1997 and ILTR in 1999. A great part of the guano extracted in the 1990s could not be transported to the mainland because the ship broke down, so it was stored in sacks and kept at the islands. Nowadays there is eventual collection of the guano stored in sacks from those days, and the number of people working to collect them may have an impact on the birds. There is talk that guano exploitation should recommence, hence its development is included as a specific objective for both MPAs. The likelihood of this happening is low because it involves a great investment in logistics that might not be justified, considering guano in these islands is of the lower quality compared to the other MPAs of the network, as the higher rainfalls at their latitudes wash out the nutrients.

The El Niño Southern Oscillation (ENSO) is not a conflict per se, more a wide-scale environmental driving force, but it is important to note that it represents the strongest environmental driver of change. By increasing sea surface temperatures, rainfall, floods and river discharge, and by reducing primary productivity in the ocean, it changes the distribution and composition of marine species and disrupts the whole ecosystem. Although the effects of climate change on ENSO remain debated, there is agreement among scientists that rainfall may become more intense in Peru [51], with consequent effects on marine productivity.

\section{GOVERNANCE FRAMEWORK/APPROACH}

\subsection{Governance framework}

Both MPAs were designated by a Supreme Decree signed by the Ministry of the Environment and the Ministry of Production (Vice-Ministry of Fisheries) under the powers of the President [52], to transfer the management of the guaneras from AGRORURAL to SERNANP. Yet, the legal framework of these MPAs is mostly provided by legislation ruled before their official designation, following institutions initiated in pre-Columbian and CAG times (Table 4).

SERNANP is in charge of the MPA network, which is centrally managed by the Administration Office of the Reserve System (Fig. 4) in coordination with these relevant public administration entities: the Maritime Authority DICAPI for surveillance, control and enforcement; the Vice-Ministry of Fisheries and the Regional Directorates of Production for regulation of marine resource use; the Institute of Marine Research IMARPE for research; AGRORURAL for guano management; the Ministry of the Environment for environmental issues; and the Vice-Ministry of Tourism for this activity. To promote

Laínez del Pozo, D. and Peter J.S. Jones (in press) Governance analysis of two historical MPAs in northern Peru: Isla Lobos de Tierra and Isla Lobos de Afuera. Marine Policy 104096 https://doi.org/10.1016/j.marpol.2020.104096 One of 20 papers in a special section of 28 case studies on MPA Governance 
cross-jurisdictional coordination, the legal framework recognises the need for a Technical Coordination Group in charge of preparing the management strategy for the whole reserve system, composed of a representative from each government agency, with SERNANP at the head. To support management and the participatory processes, the Law of Protected Areas [53] requires designating a Local Management Committee elected by local actors from the public and private sectors, which was created in 2014. To facilitate and deconcentrate management, SERNANP opened four regional offices along the coast. These two MPAs are under the office of the north sector.

Table 4. Legal framework in force at ILTR and ILAR

\begin{tabular}{|c|c|c|}
\hline Year & Regulation Title & Description \\
\hline 1992 & General Fishing Law (D.L. № 25977) & $\begin{array}{l}\text { The first } 5 \mathrm{~nm} \text { from shore are exclusively reserved } \\
\text { for artisanal fishers who have free access and } \\
\text { movement within this band. }\end{array}$ \\
\hline 2000 & Forestry and Wildlife Law (Ley № 27308) & $\begin{array}{l}\text { Bans all motorised activity } 2 \mathrm{~nm} \text { from shore of the } \\
\text { guaneras. }\end{array}$ \\
\hline 2001 & $\begin{array}{l}\text { Law of Control and Surveillance of Maritime, } \\
\text { River and Lacustrine Activities (D.S. № 028- } \\
\text { DE-MGP) }\end{array}$ & $\begin{array}{l}\text { Prohibits any kind of navigation and extractive } \\
\text { activities } 200 \mathrm{~m} \text { from shore of the guaneras. }\end{array}$ \\
\hline 2006 & $\begin{array}{l}\text { Extraction ban of Peruvian scallops at ILTR } \\
\text { (R.M.No293-2006-PRODUCE) }\end{array}$ & $\begin{array}{l}\text { Bans extraction of Peruvian scallops from the } \\
\text { seedbanks at ILTR. }\end{array}$ \\
\hline 2009 & $\begin{array}{l}\text { Supreme decree that creates the Guano } \\
\text { Islands, Islets and Capes Reserve System (D.S. } \\
\text { No024-2009-MINAM) }\end{array}$ & $\begin{array}{l}\text { Creates the reserve system that includes ILTR and } \\
\text { ILAR, establishing its objectives and operational } \\
\text { structures. }\end{array}$ \\
\hline 1997 & Protected Areas Law (Ley N² 26834) & $\begin{array}{l}\text { Provides the management and conservation } \\
\text { framework for protected areas. Became } \\
\text { applicable to the guaneras since their } \\
\text { designation. }\end{array}$ \\
\hline 2012 & $\begin{array}{l}\text { Ban of bolichito de fondo (R.M. № 303-12- } \\
\text { PRODUCE) }\end{array}$ & $\begin{array}{l}\text { Prohibits hookah diving with bottom purse-seine } \\
\text { nets in Peru. }\end{array}$ \\
\hline 2016 & $\begin{array}{l}\text { Presidential resolution that establishes the } \\
\text { reserve system's master plan (R.P. No 048- } \\
\text { 2016-SERNANP) }\end{array}$ & $\begin{array}{l}\text { Highest planning tool of the reserve system. } \\
\text { Delineates the specific objectives and strategies } \\
\text { of each unit MPA, and the zoning plans of the first } \\
\text { three pilot sites, which include ILTR. }\end{array}$ \\
\hline 2019 & $\begin{array}{l}\text { Supreme decree that establishes the National } \\
\text { Maritime Policy (D.S. № 012-2019-DE) }\end{array}$ & $\begin{array}{l}\text { Creates the policy framework to integrate state } \\
\text { action in the ocean and strengthen the } \\
\text { articulation of sectoral policies. }\end{array}$ \\
\hline
\end{tabular}

Laínez del Pozo, D. and Peter J.S. Jones (in press) Governance analysis of two historical MPAs in northern Peru: Isla Lobos de Tierra and Isla Lobos de Afuera. Marine Policy 104096 https://doi.org/10.1016/j.marpol.2020.104096 One of 20 papers in a special section of 28 case studies on MPA Governance 


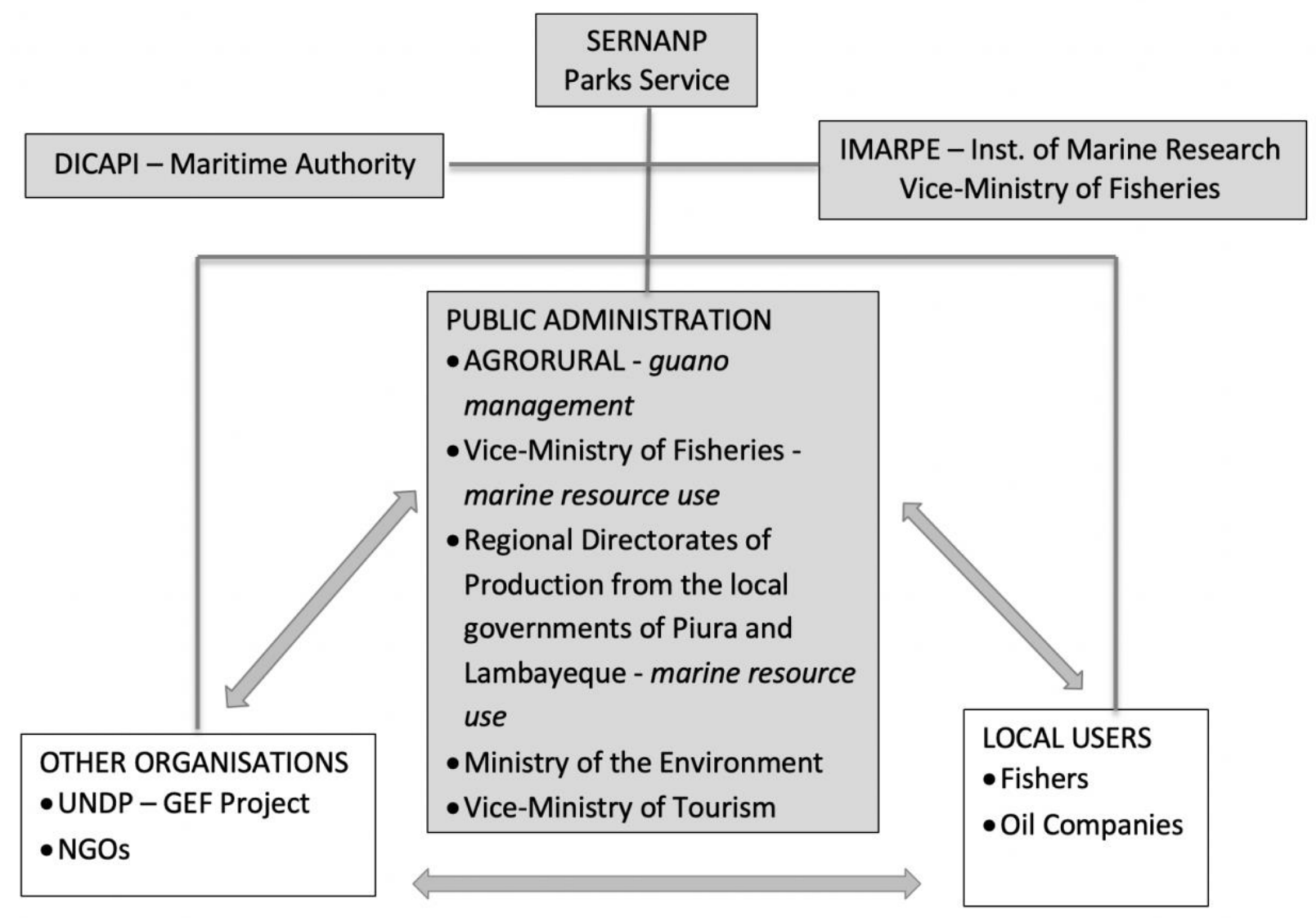

Key: Local Management Committee Technical Coordination Group

Figure 4. Governance Framework of ILTR and ILAR

\subsection{Limitations of the governance structure}

The governance framework is a continuation of structures inherited from times when protection was focused on land-based guano and birds. These MPAs are predominantly marine ( $91 \%$ ILTR, 97\% ILAR), though, SERNANP only has decisive power over the flora and fauna on land, lacking authority over the marine species it aims to protect (Table 2). These species remain the responsibility of the ViceMinistry of Fisheries and the Regional Directorates of Production (Piura and Lambayeque). SERNANP has the power to sanction poaching of seabirds but not illegal fishing. If SERNANP observes illegal extraction of spat, having no direct authority to sanction, it needs to coordinate a patrolling operation with DICAPI and the Vice-Ministry of Fisheries, with the difficulties this entails. DICAPI often responds to calls saying, 'we are sorry, but we don't have fuel to do that operation, this patrolling is not within our budget', limiting enforcement capacity. This is a common answer that illustrates the lack of crossjurisdiction coordination. It also responds to the low rank of the DICAPI base in charge of these MPAs 
which, until recently, did not have decisive power or patrol boats to act. In this sense, the Technical Coordination Group is key, but it exists only in name. Furthermore, patrol boats need to navigate over $100 \mathrm{~km}$ to reach these MPAs, meaning illegal fishers have a big-time window to be alerted before the coast guards arrive. Hence, the marine environment of these islands is relegated to the realm of informality.

"The buyer is in contact with the person bribed and he calls us: 'don't go up today because the coast guard is on the way'. No man goes to the island that day. The buyer himself warns us and the coast guard himself warns the buyer. After the coast guard leaves, the next day we're all working as if nothing happened"

- Octopus and fish diver

De jure, the legal framework seems clear, but de facto, it is challenging to operate. Coordination is difficult because each institution reports to a different authority. SERNANP reports to the Ministry of the Environment, DICAPI reports to the Peruvian Navy, IMARPE to the Vice-Ministry of Fisheries (Ministry of Production), the Regional Directorates of Production to the Regional Governments of Piura and Lambayeque, and AGRORURAL to the Ministry of Agriculture. Each institution works independently, only approaching SERNANP for approval to implement their own independent plans. In 2019 the National Maritime Policy was established to integrate marine activity and policy from all sectors and levels of government. This is expected to improve marine governance, including MPAs, though not all sectors agree with this approach, as it is led by the Council of Ministers, which is not considered the most relevant actor in this applied context.

Several governance structures remain in name only. The Local Management Committee is a crucial governance structure not effectively mobilised, partly because it is based on an inaccurate map of actors, seemingly with the aim of inflating apparent actor participation. Some actors are ghost associations only existent on paper, others want to be included as actors for political reasons when they have no relation to these MPAs, and others are expecting to benefit from future mariculture business. The current map of actors does not do justice to the traditional local users. The situation is complex because a great majority of local users are informal fishers not considered in the maps, while other people considered actors have never gone to the islands, yet, they have all the documents in place to operate legally once MPA fisheries management plans are ready. This opens the question, who should be entitled to be considered an actor?

Another reason why the committee is not mobilised is because members sense no vested interest from SERNANP to work with them:

Laínez del Pozo, D. and Peter J.S. Jones (in press) Governance analysis of two historical MPAs in northern Peru: Isla Lobos de Tierra and Isla Lobos de Afuera. Marine Policy 104096 https://doi.org/10.1016/j.marpol.2020.104096 One of 20 papers in a special section of 28 case studies on MPA Governance 
“... nothing we've achieved has been applied, it makes me feel like they are simply using us to establish a system that may work in the future, but they don't have the teeniest intention to implement now. We feel like simple actors playing a role. I feel useless, why? Because we didn't agree in some points and the final documents ignored it. I feel a little demoralized... we are only actors to fill documents" - Scallop diver, member of the Local Management Committee.

The process of deconcentration of responsibilities is another initiative with no effective management changes. The office for ILTR and ILAR is in Trujillo, $340 \mathrm{~km}$ away from the main port of embarkation to these MPAs, and decisions are still taken centrally in Lima, with no local staff from SERNANP in the vicinity.

\subsection{Current governance}

SERNANP has not assumed full management. For bureaucratic endeavours, SERNANP is responsible (e.g. issuing research permits) but for de facto protection the guardians of AGRORURAL are still in charge, though their responsibilities are limited to looking after the birds, sea lions and facilities [54]. Guardians can warn trespassers and ask them to leave, but they are not empowered to sanction like the park rangers from SERNANP are, nor do they have patrol vessels.

Current governance and the relative protection of the land-based ecosystems is the result of past top-down governance and the social assemblages that exist between guardians and fishers, since there is no enforcement in these remote spaces.

"Before, the guardians had weapons. It was forbidden for boats to approach 200 meters from the island, if they approached, guardians shot first in the air, then water. People were afraid of the guardians; they did not come near because they would bust a cap on you" - Scientist

"[The islands] have been our sustenance, and well, above all, the guardians have given us good affection, they've been good to us. In the absence of our family, the guardians have become a family. They are very, very good to us, all of us who have known them for all the years working on the islands. I met guardian J, guardian $K$, the current guardian L, M, M's dad. Now he's on the high island, M's dad. The first guardian I met 
was Mr. N, the old man who lives there with him, we've also worked there. All were good times thanks to their help, they allowed us to enter, fishing in the areas that others don't access because it's forbidden. We have never been denied anything ..." Gill net fisher

Guardians are dependent on fishers to reach their workplace, creating a fraternal complicity that makes enforcement problematic. However, respect for the role of the guardian and the will to maintain convivial relations seems to prevail in benefit of the land ecosystem. Fishers do not respect regulations to protect the marine environment (Table 4), though there is care by most fishers not to breach the landing ban for which guardians are responsible. Fishers sleep on their boats at sea during their week-long stays. They are usually respectful to ask the guardians permission to land (i.e. to make phone calls from higher ground, repair their boats, play football). This responds to fraternal ties maintained through a history of special concessions to traditional fishers in the Lobos Islands and a tradition of vertical complementarity, where most guardians come from the Andes and take the role through family to keep their access to guano for their farms.

In ILAR there is also protection by fishers who self-mobilised, without support from SERNANP, to remove fishing they consider impactful. There is also staff from the Peruvian Navy in charge of the lighthouse, who many fishers believe perform a surveillance role, acting as a deterrent for illegal activities for some fishers.

\section{EFFECTIVENESS}

\subsection{Effectiveness measures}

Interventions to address the conservation and operational objectives have revolved around protecting the land area from trespassers and monitoring guano bird and sea lion populations. These activities help maintain the insular ecosystem and its species as relatively protected, though they are not an initiative of SERNANP. Monthly wildlife surveys are conducted by AGRORURAL and an annual census of sea lions is led by IMARPE. Both activities remain as a legacy from the times of the CAG.

Initial efforts by SERNANP focused on resolving paperwork: the master plan of the reserve system 2016-2020, the maps of social actors and the zoning plan of ILTR, which were not sufficiently based on local realities. What SERNANP has done de facto to address MPA objectives is hire NGO Pro Delphinus in 2017 to run a project aimed at strengthening the sustainable management of ILAR and

Laínez del Pozo, D. and Peter J.S. Jones (in press) Governance analysis of two historical MPAs in northern Peru: Isla Lobos de Tierra and Isla Lobos de Afuera. Marine Policy 104096 https://doi.org/10.1016/j.marpol.2020.104096 One of 20 papers in a special section of 28 case studies on MPA Governance 
design its zoning plan, with a GEF funding of USD 372,100 [55]. The project was intended to cover biological, social and economic aspects, with a focus on characterising fisheries and formalising the octopus fishery.

SERNANP also signed a conservation agreement with a group of handliners in ILAR, who signed in their need of recognition as traditional users. Hookah divers refrained from signing due to an inadequate social intervention and miscommunication. The conservation agreement was an objective set for ILTR (Table 2), where actors are more impactful and elusive, but there have not been interventions on site, and approaches have been on paper except for a couple of beach clean-up campaigns organised by SERNANP.

\subsection{Limitations of the effectiveness measures}

In these MPAs, conditions and actors change throughout the year. To intervene effectively it is key to understand the complexities of these MPAs, to meet all the actors and to gain their trust, but the contract for the intervention of Pro Delphinus was for only 15 months, a common caveat with development projects. Other limitations might be that the NGO's expertise is in marine and fisheries biology but not in governance. Furthermore, the project was restricted to the octopus fishery out of all other conservation species (Table 2). Important outputs planned for this intervention, such as the zoning plan for ILAR and the conservation agreement with octopus divers, could not be delivered. A longer framed project, larger in scope, with experienced marine social scientists would have helped build rapport and improve the project's impact.

Despite the relative protection of the land ecosystems and their species, this represents less than $10 \%$ of the area protected in both MPAs. The rest is marine environment where intervention is lacking.

\subsection{Effectiveness score}

The recent NGO intervention in ILAR, together with the progress made with paperwork in ILTR, are small steps that slightly address some of the objectives of these MPAs, giving them an equal effectiveness score of 1 (out of 5) on the scale of the MPA governance framework [3], i.e. some impacts beginning to be slightly addressed. This is explained in detail in the introduction paper of this special section [4] 


\section{INCENTIVES}

Following the MPAG framework [3,4] incentives are the institutions designed for MPAs "to encourage actors to choose to behave in a manner that provides for certain strategic policy outcomes, particularly biodiversity conservation and restoration objectives, to be achieved" [3 p.104, 4]. Several incentives are particularly important to introduce to strengthen the framework (Table 5), but few have been initiated by SERNANP and they are in their initial stages, most of them in need of considerable strengthening. The most effective incentives are legal and were established before the MPA designation (Table 4).

Table 5. Isla Lobos de Tierra ILTR and Isla Lobos de Afuera ILAR - Incentives applied (Y), including those that are particularly important priorities for strengthening $\left(\mathrm{Y}^{*}\right)$ and introducing $\left(\mathrm{N}^{*}\right)$

\begin{tabular}{|c|c|c|}
\hline Incentive type & Used & How/Why \\
\hline $\begin{array}{l}\text { Economic } \\
\text { 2. Assigning Property } \\
\text { Rights }\end{array}$ & $\mathrm{N}^{*}$ & $\begin{array}{l}\text { Local users have high expectations on concessions for mariculture } \\
\text { (temporary property rights), but the specific regulations for these } \\
\text { have not been established. }\end{array}$ \\
\hline $\begin{array}{l}\text { 4. Promoting } \\
\text { profitable and } \\
\text { sustainable fishing } \\
\text { and tourism }\end{array}$ & $\mathrm{Y}^{*}$ & $\begin{array}{l}\text { ILTR has a zoning plan [56] to regulate fishing, but it has } \\
\text { incoherencies that need to be resolved, i.e. resource-use zones } \\
\text { overlap with sea turtle feeding areas [57], Nazca booby breeding } \\
\text { colonies [58] and areas banned for navigation and extractive } \\
\text { activities by other regulations (Table 4). }\end{array}$ \\
\hline $\begin{array}{l}\text { 5. Promoting green } \\
\text { marketing }\end{array}$ & $Y^{*}$ & $\begin{array}{l}\text { There is a nation-wide government programme called "Let's eat } \\
\text { fish!" to promote sustainably sourced fish, connecting fishers } \\
\text { directly with buyers for better prices. A campaign for these MPAs } \\
\text { was discussed but the difficulty of keeping fish fresh from an area } \\
\text { so remote is an obstacle. }\end{array}$ \\
\hline $\begin{array}{l}\text { 9. Provision of state } \\
\text { funding }\end{array}$ & $\mathrm{Y}^{*}$ & $\begin{array}{l}\text { Both MPAs received one-year funding from the Global } \\
\text { Environmental Facility (GEF) to strengthen their governance. This } \\
\text { was too short-term and limited, hence there is still no budget to } \\
\text { cover for park rangers from SERNANP and other basic operational } \\
\text { costs. }\end{array}$ \\
\hline $\begin{array}{l}\text { 10. Provision of NGO, } \\
\text { private sector and } \\
\text { user fee funding }\end{array}$ & $\mathrm{Y}^{*}$ & $\begin{array}{l}\text { User fees have been collected in ILTR from a cruise ship that } \\
\text { stopped randomly a couple of times with small numbers of } \\
\text { tourists, without generating significant income. NGO Asociación } \\
\text { para la Investigación y Conservación de la Biodiversidad (AICB) } \\
\text { conducted the first studies on the ecology and conservation } \\
\text { status of these islands. }\end{array}$ \\
\hline
\end{tabular}

Laínez del Pozo, D. and Peter J.S. Jones (in press) Governance analysis of two historical MPAs in northern Peru: Isla Lobos de Tierra and Isla Lobos de Afuera. Marine Policy 104096 https://doi.org/10.1016/j.marpol.2020.104096 One of 20 papers in a special section of 28 case studies on MPA Governance 


\begin{tabular}{|c|c|c|}
\hline $\begin{array}{l}\text { Communication } \\
\text { 11. Raising awareness }\end{array}$ & $Y^{*}$ & $\begin{array}{l}\text { Leaflets, posters and videos were produced without significant } \\
\text { impact. They were disseminated in the meetings of the Technical } \\
\text { Coordination Group, the Local Management Committee, social } \\
\text { media and national TV, not reaching the local users. }\end{array}$ \\
\hline $\begin{array}{l}\text { 13. Promoting } \\
\text { recognition of } \\
\text { regulations and } \\
\text { restrictions }\end{array}$ & $\mathrm{N}^{*}$ & $\begin{array}{l}\text { Not yet focused on, but SERNANP recently approached the Local } \\
\text { Management Committee to ask them for the best channel to } \\
\text { disseminate regulations and restrictions so that the information } \\
\text { is not lost. ILTR's zoning plan has not been disseminated among } \\
\text { local users to prevent requests for fishing concessions. SERNANP } \\
\text { still wants to build capacity and a solid legal framework. }\end{array}$ \\
\hline $\begin{array}{l}\text { Knowledge } \\
\text { 14. Promoting } \\
\text { collective learning }\end{array}$ & $\mathrm{N}^{*}$ & $\begin{array}{l}\text { While research has not been impeded, it has not been } \\
\text { encouraged or communicated. Important published knowledge } \\
\text { has not been drawn-on in management documents (e.g. turtle } \\
\text { feeding areas overlap with resource extraction zones in ILTR). } \\
\text { Handliners also complain their knowledge is not considered. }\end{array}$ \\
\hline $\begin{array}{l}\text { 16. Independent } \\
\text { advice and arbitration }\end{array}$ & $\mathrm{N}^{*}$ & $\begin{array}{l}\text { IMARPE should provide independent advice and arbitration on } \\
\text { future resource management plans, though some actors, } \\
\text { particularly fishers, do not consider IMARPE neutral due to its } \\
\text { dependency on the Vice-Ministry of Fisheries and corruption } \\
\text { related accusations [59]. }\end{array}$ \\
\hline $\begin{array}{l}\text { Legal } \\
\text { 17. Hierarchical } \\
\text { obligations }\end{array}$ & $\mathrm{Y}^{*}$ & $\begin{array}{l}\text { The MPA designations respond to the obligations of Aichi } \\
\text { Biodiversity Target № } 11 \text { and Sustainable Development Goal № } \\
\text { 14, but societal actors agree there is no political will to make } \\
\text { them effective, perhaps because these obligations are not legally } \\
\text { binding. }\end{array}$ \\
\hline $\begin{array}{l}\text { 18. Capacity for } \\
\text { enforcement }\end{array}$ & $\mathrm{N}^{*}$ & $\begin{array}{l}\text { It is a common perception that there is no budget and no } \\
\text { coordination for enforcement due to the lack of political will and } \\
\text { corruption. }\end{array}$ \\
\hline $\begin{array}{l}\text { 19. Penalties for } \\
\text { deterrence }\end{array}$ & $\mathrm{Y}^{*}$ & $\begin{array}{l}\text { There are no specific penalties for these MPAs, though penalties } \\
\text { of the General Fishing Law apply, e.g. for fishing below the } \\
\text { permitted minimum sizes, fishing with prohibited gear, etc. }\end{array}$ \\
\hline $\begin{array}{l}\text { 20. Protection from } \\
\text { incoming users }\end{array}$ & $\mathrm{Y}^{*}$ & $\begin{array}{l}\text { Legislation prior to the MPAs designation (Table 4) and ILTR's } \\
\text { zoning plan regulates access, but there are no actual means or } \\
\text { resources for enforcement. In the future, only fishers with MPA } \\
\text { licenses should be granted access, hence the importance of } \\
\text { conservation agreements with fishers and the formalisation of } \\
\text { fishers initiated by the local government. }\end{array}$ \\
\hline
\end{tabular}

Laínez del Pozo, D. and Peter J.S. Jones (in press) Governance analysis of two historical MPAs in northern Peru: Isla Lobos de Tierra and Isla Lobos de Afuera. Marine Policy 104096 https://doi.org/10.1016/j.marpol.2020.104096 One of 20 papers in a special section of 28 case studies on MPA Governance 


\begin{tabular}{|c|c|c|}
\hline $\begin{array}{l}\text { 21. Attaching } \\
\text { conditions to use and } \\
\text { property rights, } \\
\text { decentralisation, etc }\end{array}$ & $\mathrm{N}^{*}$ & $\begin{array}{l}\text { According to the legal framework, fishing and mariculture should } \\
\text { only be conducted by MPA licensed fishers under management } \\
\text { plans specific for each site, prepared in coordination between the } \\
\text { Vice-Ministry of Fisheries, SERNANP and the local governments. } \\
\text { These plans, along with related conditions to use, have not been } \\
\text { implemented yet. }\end{array}$ \\
\hline $\begin{array}{l}\text { 22. Cross-jurisdictional } \\
\text { coordination }\end{array}$ & $Y^{*}$ & $\begin{array}{l}\text { The Technical Coordination Group rarely meets, there are no } \\
\text { operational guidelines. Improved cross-jurisdictional } \\
\text { coordination is required between SERNANP and the following } \\
\text { entities: DICAPI to enforce protection; IMARPE to promote } \\
\text { collective learning; the Vice-Ministry of Fisheries to elaborate } \\
\text { fisheries management plans, especially for Peruvian scallops. }\end{array}$ \\
\hline $\begin{array}{l}\text { 23. Clear and } \\
\text { consistent legal } \\
\text { definitions }\end{array}$ & $\mathrm{N}^{*}$ & $\begin{array}{l}\text { Some of the conservation objectives and the zoning plan of ILTR } \\
\text { are not specific enough and their scientific basis is questioned by } \\
\text { scientists. More legal definitions are needed to adequately define } \\
\text { the social actors and establish limitations to human activities, } \\
\text { sanctions, etc. }\end{array}$ \\
\hline $\begin{array}{l}\text { 24. Clarity concerning } \\
\text { jurisdictional } \\
\text { limitations }\end{array}$ & $\mathrm{N}^{*}$ & $\begin{array}{l}\text { SERNANP is responsible for the MPAs' management but it does } \\
\text { not have legal competence over marine resources, only } \\
\text { attributed to the Vice-Ministry of Fisheries and the Regional } \\
\text { Directorates of Production from Piura and Lambayeque. This } \\
\text { limits SERNANP's capacity to regulate fisheries' activities, } \\
\text { undermining the MPAs' governance, being a limitation that } \\
\text { needs to be recognised and rectified through either improved } \\
\text { cross-jurisdictional coordination (I-22) or the transfer of fisheries } \\
\text { management responsibilities in these (and other) MPAs to } \\
\text { SERNANP. }\end{array}$ \\
\hline $\begin{array}{l}\text { 26. Transparency, } \\
\text { accountability and } \\
\text { fairness }\end{array}$ & $\mathrm{N}^{*}$ & $\begin{array}{l}\text { There is a general perception that there is a lack of transparency, } \\
\text { accountability and fairness, due to rushed requests from } \\
\text { SERNANP to social actors to approve documents without } \\
\text { adequate time for revision. }\end{array}$ \\
\hline $\begin{array}{l}\text { Participation } \\
\text { 27. Rules for } \\
\text { Participation }\end{array}$ & $\mathrm{N}^{*}$ & $\begin{array}{l}\text { No clear rules, and the map of actors is not representative of the } \\
\text { MPAs' social configuration. Actors complain they are asked for } \\
\text { their opinions but are not considered, leaving their involvement } \\
\text { at the level of passive participation [60]; only informed about } \\
\text { SERNANP's decisions. }\end{array}$ \\
\hline
\end{tabular}

Laínez del Pozo, D. and Peter J.S. Jones (in press) Governance analysis of two historical MPAs in northern Peru: Isla Lobos de Tierra and Isla Lobos de Afuera. Marine Policy 104096 https://doi.org/10.1016/j.marpol.2020.104096 One of 20 papers in a special section of 28 case studies on MPA Governance 


\begin{tabular}{|c|c|c|}
\hline $\begin{array}{l}\text { 28. Establishing } \\
\text { collaborative } \\
\text { platforms }\end{array}$ & $Y^{*}$ & $\begin{array}{l}\text { The Local Management Committee is the platform created for the } \\
\text { state and civil society to collaborate. This committee meets } \\
\text { rarely, only to fulfil the participatory obligations of protected area } \\
\text { management, i.e. tokenistic collaboration. }\end{array}$ \\
\hline 29. Neutral facilitation & $\mathrm{N}^{*}$ & $\begin{array}{l}\text { Facilitation is led by SERNANP but social actors do not perceive } \\
\text { them to be neutral. }\end{array}$ \\
\hline $\begin{array}{l}\text { 31. Decentralising } \\
\text { responsibilities }\end{array}$ & $\mathrm{Y}^{*}$ & $\begin{array}{l}\text { The MPA units of the reserve system are managed by four } \\
\text { regional offices, but there is no decentralisation in practice. All } \\
\text { decisions are still made centrally in Lima, undermining the local } \\
\text { specificity and appropriateness of management approaches. }\end{array}$ \\
\hline 32. Peer enforcement & $\begin{array}{l}N^{*}-\text { ILTR } \\
Y^{*}-\text { ILAR }\end{array}$ & $\begin{array}{l}\text { Peer enforcement only occurs in ILAR. Local users protect it from } \\
\text { impactful fishing, though some of these same fishers also have } \\
\text { an impact, e.g. landing to make phone calls, repair boats, play } \\
\text { football or fish in banned areas. }\end{array}$ \\
\hline $\begin{array}{l}\text { 33. Building trust and } \\
\text { the capacity for } \\
\text { cooperation }\end{array}$ & $\mathrm{N}^{*}$ & $\begin{array}{l}\text { There is little trust. In the ten years of the MPAs, nothing has been } \\
\text { done de facto in situ to protect these areas and achieve the } \\
\text { conservation objectives. }\end{array}$ \\
\hline $\begin{array}{l}\text { 34. Building linkages } \\
\text { between relevant } \\
\text { authorities and user } \\
\text { representatives }\end{array}$ & $\mathrm{N}^{*}$ & $\begin{array}{l}\text { Meetings are rare, less than once a year, and it does not help that } \\
\text { authorities change constantly for political reasons. }\end{array}$ \\
\hline
\end{tabular}

\section{CROSS CUTTING ISSUES/FACTORS}

\subsection{Equity issues}

People have been historically banned from landing or fishing at these MPAs, so no one has been recently affected by conservation restrictions. Even if fishers do not know about the MPA status, they know about the earlier regulations (Table 4). Before their designation, the areas protected in ILTR $\left(16.2 \mathrm{~km}^{2}\right)$ and ILAR $\left(2.8 \mathrm{~km}^{2}\right)$ were mostly land and included a $200 \mathrm{~m}$ fringe of surrounding sea that served as a protective buffer. With the official designation, the increased protected areas are mainly marine areas. ILTR now covers $182.8 \mathrm{~km}^{2}$ where $91 \%$ is ocean, and ILAR covers $82.7 \mathrm{~km}^{2}$ where $97 \%$ is ocean [56]. This will create future fishing regulations that could raise equity issues if additional restrictions are introduced and enforced. This will depend greatly on the criteria that SERNANP 
chooses to define users and related social actors, including their rights, which have already started to raise equity concerns.

\subsection{Role of NGOs}

In the 1990s a group of NGOs formed the consortium BIOMAR to promote the designation of the Guano Islands, Islets and Capes Reserve System [49]. After the official designation, the NGOs continued to support the governance of their specific MPAs of interest, and ILTR and ILAR were not supported by any NGO. Until 2017, AICB was the only NGO that had worked in these MPAs, and it was not part of BIOMAR. From 1999 onwards AICB conducted biodiversity studies and prepared the main documents about the ecology and conservation status of these MPAs, but SERNANP did not consider these contributions when designing the zoning plan of ILTR $[6,61]$. Apart from them, no other NGO intervened until September 2017 when SERNANP hired Pro Delphinus to strengthen the sustainable management of ILAR.

\subsection{Role of leadership}

There is no leadership from the central government. The BIOMAR consortium supported the designation of these MPAs because they were part of an MPA network 'package'. A government officer involved in the process tried to lead the governance of these MPAs by raising awareness and promoting research, but he did not get political or monetary support, resigned after a couple of years, and no one continued this effort. ILTR and ILAR might be the MPAs with the least attention because of their remoteness. In ILAR, governance is enacted locally by fishers who fish regularly in this area and maintain a sense of stewardship for the resources of the island.

\subsection{Promoting stewardship and existing cultures and practices that facilitate it}

Participatory processes and efforts to promote stewardship need to be improved. In ILTR, lack of enforcement has led to the displacement of traditional fishing by divers, dispossessing the traditional stewards of the island. In ILAR, local users are self-motivated to keep out the highly impactful hookah divers with nets. Being the most offshore island, small and rich in resources, it is relatively easy for local users to patrol. It also helps that fishers in ILAR are a small group of regular fishers who share a sense of belonging that encourages stewardship among them. Some of these fishers also fish in ILTR but they have not organised themselves to protect it because it is much larger and more difficult, while in ILAR their efforts give them direct positive results. 


\section{CONCLUSION AND PROSPECTS}

Governance is strongly influenced by history in these MPAs. The legacy of strict top-down enforcement in the past and the long coexistence of guardians and fishers both seem to foster the current governance and protection of these remote islands far from the rule of law.

The main current drivers and conflicts are related to fishing, for which SERNANP does not have direct authority, hence it is not sufficiently regulated or enforced. Management plans specific to each MPA are urgently needed, given fish productivity is the source of richness and diversity in these islands. Eradicating the dominant informality is also key as it perpetuates marine degradation and corrupted spaces, but it will be difficult to break since people earn considerable money from it, and it occurs at all levels. Nevertheless, without correcting it all other efforts will be in vain. Formalising fishers has been a first step undertaken by the Regional Directorates of Production in their work towards specific MPA licenses that will be required in the near future. These interventions require a thorough analysis and in-depth understanding of the social dimension of these MPAs by SERNANP to avoid exacerbating or raising new equity issues.

In ILTR the prospects do not bode well. The international scallop market is a very strong driver that requires robust management measures and strict enforcement. It may also require intervention from the European Union, being the greatest importer of Peruvian scallops despite the published knowledge that most of the spat used in mariculture (75-90\%) is illegally extracted from ILTR $[20,43]$. Recovering the stewardship of ILTR seems very unlikely. Hookah divers have greatly displaced handliners, who were the traditional stewards of the island. Most local users are now a diverse incohesive group of migrants from all along the coast with a reckless 'wing it' approach to diving safety that leads to high diving fatalities and no sense of belonging to ILTR.

In ILAR the prospects seem better. Social organisation is one of its advantages, as local fishers have self-organised successfully to expel trespassers who use illegal gear and practices. However, the demand for fish continues to increase as marine resources are becoming scarcer closer to the coast, posing a great threat to ILAR as enforcement by local fishers could be insufficient to address the expanding and diversifying fishing efforts. Still, the self-organisation capacity evident at ILAR is uncommon and an opportunity that SERNANP should draw on and strengthen. Key to this end is to work closer and diligently with the local social actors. Though it is positive that the parks service hired Pro Delphinus to support its management for one year, there is still an urgent need to strengthen the governance of the MPA and the related participatory processes.

Laínez del Pozo, D. and Peter J.S. Jones (in press) Governance analysis of two historical MPAs in northern Peru: Isla Lobos de Tierra and Isla Lobos de Afuera. Marine Policy 104096 https://doi.org/10.1016/j.marpol.2020.104096 One of 20 papers in a special section of 28 case studies on MPA Governance 
Despite the poor state intervention and few incentives initiated to achieve conservation objectives, these two MPAs have the advantage that their land area was protected for a hundred years before their official designation. The land ecosystem and its species remain relatively protected thanks to the legacy of their historical governance, highlighting the crucial role that historical interactions can play in the governance of protected areas, an incentive that is often not explicitly recognised and should be strengthened in areas where humans have protected their resources since immemorial times. Yet, historical arrangements and local governance are not strong enough to stand the tests of the growing scale and diversity of extractive users, considering the strong driving forces behind them, and neither is a solely state-led approach when faced with an absent state, as performance has demonstrated thus far. A combination of bottom-up and top-down approaches is necessary and the recomposition of a diligent state is key for it to work.

\section{AUTHORSHIP CONTRIBUTION STATEMENT}

Daniela Laínez del Pozo: Conceptualization, Formal analysis, Investigation, Writing - original draft, Visualization, Project administration, Funding acquisition. Peter JS Jones: Conceptualization, Writing - review \& editing.

\section{DECLARATION OF COMPETING INTEREST}

There are no conflicts of interest associated to this research. The views presented in this paper are those of the authors only. Funders played no role at any stage.

\section{ACKNOWLEDGEMENTS}

Special thanks to all the anonymous collaborators who kindly offered their time and support. To Marco Carpio, the fishers and guardians of ILTR, Martha Martínez, Yelka Pastor and Liz Leon for making fieldwork possible. Caroline Garaway and Judith Figueroa for their valuable comments on the first draft of the manuscript. Martha del Pozo for transcribing the interviews. Cinthia Irigoin and Carla Cepeda from AGRORURAL for facilitating bird statistics and accommodation in the islands. Jose Allemant from PRODUCE for the fish statistics. Mariano Valverde and Milena Roca from SERNANP for authorising and supporting the project in these MPAs. Viviana Siveroni for archaeological literature, Gabriella Torres Alva for the final production revision and the two anonymous reviewers for their valuable feedback to the manuscript.

This research was primarily supported by funding from INNOVATE PERÚ (№089-FINCYT-BDE-2014); WWF Russell E. Train Education for Nature program, US (\#SW35), and the UCL Cross-disciplinary Training Scholarship, UK. Secondary funding was provided by Cleveland Metroparks Zoo and the 
Cleveland Zoological Society, US, and the Royal Geographical Society (with IBG), UK, with a Dudley Stamp Memorial Award.

\section{REFERENCES}

[1] G.T. Cushman, Guano and the opening of the Pacific world: a global ecological history, Cambridge Univ. Press, New York, NY, 2014.

[2] D. Laínez del Pozo, Working title: Articulating Sustainability and Conservation in Marine Protected Areas in Northern Peru, Unpublished manuscript of PhD thesis, University College London, 2020.

[3] P.J.S. Jones, Governing marine protected areas: resilience through diversity, Routledge, New York, 2014

[4] P.J.S. Jones, Long, Placeholder for the introduction and discussion paper, Marine Policy. (2020).

[5] P. Ramírez, J. De la Cruz, J. Castro, E. Barriga, Biodiversidad marina en la Isla lobos de Tierra, Perú, IMARPE, Callao, Perú, 2015.

[6] M. Stucchi, J. Figueroa, La avifauna de las Islas Lobos de Afuera y algunos alcances sobre su biodiversidad, Asociación Ucumari, Lima, Peru, 2006.

http://www.imarpe.gob.pe/chiclayo/avifauna/Avifauna.pdf.

[7] I. García-Godos, Revisión de las interacciones entre cetáceos y la pesquería marina peruana; perspectivas para la conservación de los cetáceos en Perú, in: Memorias Del Taller de Trabajo Sobre El Impacto de Las Actividades Antropogénicas En Mamíferos Marinos En El Pacífico Sudeste, CPPS/PNUMA, Bogota, Colombia, 2007.

[8] J.A. Cursach, J.R. Rau, S. Gelcich, J. Rodríguez-Maulén, Situación poblacional del pelícano peruano (Pelecanus thagus) en Chile: prospección inicial, Ornitología Tropical. (2018) 77-89. [9] J. Figueroa, L. Timana, C. Gutierrez, M. Roca, W. Hernandez, R. Ramirez, Islas Lobos de Afuera (Lambayeque): Caracterización de la fauna silvestre: aves, mamíferos y reptiles., SERNANP, Lima, Peru, 2016.

[10] C. Wiener, Pérou et Bolivie Récit de Voyage, suivi d'études archéologiques et ethnographiques et de notes sur l'écriture et les langues de populations indiennes, Typographie A. Lahure, Paris, 1880. https://archive.org/details/prouetbolivierc00wiengoog/page/n8 (accessed July 30, 2019).

[11] M. Rostworowski, Recursos naturales renovables y pesca, siglos XVI y XVII: Curacas y sucesiones, Costa Norte, 2nd ed, IEP, Instituto de Estudios Peruanos, Lima, Perú, 2005.

[12] G. de la Vega, H.V. Livermore, Royal commentaries of the Incas and General history of Peru. 1, 1. paperback print.-1987, Univ. of Texas Press, Austin, 1987. 
[13] E.G.C. Barrow, M.W. Murphree, Community conservation from concept to practice: a practical framework, Institute for Development Policy and Management, University of Manchester, Manchester, 1998.

[14] J.V. Murra, Andean societies, Ann. Rev. Anthropol. 13 (1984) 119-141.

[15] G. Portocarrero Maisch, Rostros criollos del mal: cultura y transgresión en la sociedad peruana, 1. ed, Red para el Desarrollo de las Ciencias Sociales en el Perú [u.a.], Lima, 2004.

[16] J. Basadre, Historia de la República del Perú [1822 - 1933], Empr. Ed. El Comercio, Lima, 2005.

[17] A. Raimondi, Explotación del Guano - Islas, islotes y rocas del Perú, CAG, Lima, Perú, 1926. http://biblioimarpe.imarpe.gob.pe/handle/123456789/2828 (accessed July 19, 2019).

[18] X. Velez-Zuazo, A.S. Pacheco, S. Kelez, C. Cespedes, Historical baseline of diversity and abundance of Peruvian marine mega-vertebrates to disentangle climate from fisheries effects, Lima, Perú, 2012.

[19] República del Perú, Sentencia del Tribunal Constitucional - EXP. N.O 0022-2003-AI/TC, 2004. http://www.tc.gob.pe/jurisprudencia/2004/00022-2003-Al.pdf (accessed September 16, 2019). [20] J. Mendo, M. Wolff, T. Mendo, L. Ysla, Scallop Fihsery and Culture in Peru, in: S.E. Shumway, G.J. Parsons (Eds.), Scallops: Biology, Ecology, Aquaculture, and Fisheries, Third edition, Elsevier, Amsterdam ; Boston, 2016: pp. 1089-1110.

[21] SERNANP, Expediente Técnico: Establecimiento de la Reserva Nacional Sistema de Islas, Islotes y Puntas Guaneras, (2009).

[22] Peru, Chile, Tratado de Paz de Ancón, 1883.

http://www4.congreso.gob.pe/comisiones/1999/exteriores/chile/ANCON.htm (accessed November 2, 2019).

[23] D.C. Duffy, Environmental uncertainty and commercial fishing: Effects on Peruvian guano birds, Biological Conservation. 26 (1983) 227-238. https://doi.org/10.1016/0006-3207(83)90075-7.

[24] WALSH, Estudio de Impacto Ambiental para la perforación exploratoria en el lote Z-35, (2011).

[25] M. Bouchon, P. Ayón, J. Mori, C. Peña, P. Espinoza, L. Hutchings, B. Buitrón, A. Perea, C. Goicochea, M. Messié, Biología de la anchoveta peruana, Engraulis ringens Jenyns, Bol. Inst. Mar Perú. 25 (2010) 23.

[26] PRODUCE, Anuario Estadístico Pesquero y Acuícola, Estadística Pesquera Mensual, Ministerio de la Producción, Lima, Perú, 2018.

[27] E. Goya, Abundancia de aves guaneras y su relación con la pesquería de anchoveta peruana de 1953 a 1999, IMARPE, Callao, Perú, 2000.

[28] R. Murphy, El guano y la pesca de anchoveta, American Museum of Natural History, New York, 1954.

Laínez del Pozo, D. and Peter J.S. Jones (in press) Governance analysis of two historical MPAs in northern Peru: Isla Lobos de Tierra and Isla Lobos de Afuera. Marine Policy 104096 https://doi.org/10.1016/j.marpol.2020.104096 One of 20 papers in a special section of 28 case studies on MPA Governance 
[29] AGRORURAL, Programa de Desarrollo Productivo Agrario Rural, Ministerio de Agricultura Del Perí. (2018). https://www.minagri.gob.pe/portal/download/pdf/rediagro/2018/exposicionesminagriatualcance/lima/servicios-agrorural.pdf (accessed November 7, 2019).

[30] CAG, Leyes y Resoluciones.- El accesso de pescadores a los grupos de Lobos, CAG, Lima, Perú, 1925. http://biblioimarpe.imarpe.gob.pe/handle/123456789/2828 (accessed July 19, 2019).

[31] INRENA, Plan Director del Sistema Nacional de Areas Naturales Protegidas por el Estado, INRENA, Lima, Perú, 1995.

[32] Républica del Perú, Ley de Creación del Proyecto Especial de Promoción del Aprovechamiento de Abonos Provenentes de Aves Marinas, 1997.

[33] Républica del Perú, Ley N²7308 .- Ley Forestal y de Fauna Silvestre, 2000.

http://www.leyes.congreso.gob.pe/Documentos/Leyes/27308.pdf (accessed September 18, 2019).

[34] República del Perú, Reglamento de la Ley de Control y Vigilancia de las Actividades Marítimas, Fluviales y Lacustres, 2001.

http://www2.congreso.gob.pe/Sicr/Comisiones/2004/Ambiente_2004.nsf/Documentosweb/84336 3954170F21A05256F32005504C7/\$FILE/DS028-2001-DE-MGP.pdf (accessed November 6, 2019).

[35] J. Mendo, H. Orrego, M. Miglio, P. Gil, A. Del Solar, Manual tecnico para el repoblamiento de la concha de abanico en Bahia Sechura, FINCYT, 2011.

[36] M.-C. Badjeck, J. Mendo, M. Wolff, H. Lange, Climate variability and the Peruvian scallop fishery: the role of formal institutions in resilience building, Climatic Change. 94 (2009) 211-232. https://doi.org/10.1007/s10584-009-9545-y.

[37] W. Carbajal Villata, Identificación de grupos de interés en el Golfo de Sechura y litoral de Lambayeque tanto a nivel de conocimientos, actitudes y prácticas así como a nivel de levantamiento de percepciones y expectativas, respecto al área protegida, fauna y recursos marinos de la Isla Lobos de Tierra (ILT), UNDP, Lima, Perú, 2013.

[38] Tribunal Constitucional, Sentencia del Tribunal Constitucional, Perú, 2004. http://www.tc.gob.pe/jurisprudencia/2004/00022-2003-Al.pdf (accessed March 19, 2018). [40] D. Moscol, Bayóvar: delincuencia, manejos inadecuados y grifos flotantes, El Tiempo. (2016). https://eltiempo.pe/bayovar-delincuencia-manejos-inadecuados-y-grifos-flotantes/ (accessed July 11, 2019).

[41] J. De la Cruz, P. Ramirez, J. Castro, J. Galán, U. Neira, O. García, Caracterización de los elementos de conservación del ecosistema marino en las islas Lobos de Afuera (Lambayeque), 2016, in: Línea Base Biológica Terrestre y Marina de La Islas, Islotes y Puntas Guaneras - Reserva Nacional Sistema de Islas Lobos de Afuera (Lambayeque), SERNANP, Lima, Perú, 2019.

[42] M. Akester, Humboldt Project: Report on Visit to the Isla Lobos de Tierra Pilot Site, UNDP, Lima, Peru, 2011. http://humboldt.iwlearn.org/es/sitios-piloto/-

1/Humboldt_Project_Report_Lobos_Feb_2012_Compact.pdf.

Laínez del Pozo, D. and Peter J.S. Jones (in press) Governance analysis of two historical MPAs in northern Peru: Isla Lobos de Tierra and Isla Lobos de Afuera. Marine Policy 104096 https://doi.org/10.1016/j.marpol.2020.104096 One of 20 papers in a special section of 28 case studies on MPA Governance 
[43] J. Mendo, Diagnostico de la Acuicultura Marina en la Region Piura, (2016).

[44] El Tiempo, Sechura producirá hasta 15 millones de mallas de concha de abanico, El Tiempo. (2019). https://eltiempo.pe/sechura-producira-hasta-15-millones-de-mallas-de-concha-de-abanico/ (accessed October 29, 2019).

[45] C.M. Salazar Céspedes, F. Ganoza Chozo, G. Chacón Nieto, J. Alarcón Velez, E. Barriga Rivera, M. Huerto Rengifo, A. Rodríguez Flores, J. Macalupú Rosado, Evaluación técnica de la red de encierre activada por buzos o bolichito de fondo, IMARPE, 2015.

http://biblioimarpe.imarpe.gob.pe/handle/123456789/2986 (accessed December 14, 2019).

[46] República del Perú, Resolución Ministerial, 2012.

http://www2.produce.gob.pe/dispositivos/publicaciones/2012/junio/rm303-2012-produce.pdf (accessed March 20, 2019).

[47] D. Lainez del Pozo, Pescador artesanal vs. pesca artesanal, La República. (2019).

https://larepublica.pe/economia/2019/11/16/daniela-lainez-pescador-artesanal-vs-pescaartesanal/ (accessed December 5, 2019).

[48] PeruPetro, Mapa del Perú: Lotes de Contrato y Pozos Exploratorios, (2018).

http://www.perupetro.com.pe/wps/wcm/connect/corporativo/2bf00e68-f2bf-4bc9-ad86eef331d846c0/Mapa+de+Lotes+de+Contrato+y+Pozos+Exploratorios+Setiembre+2018. pdf?MOD=A JPERES (accessed August 11, 2018).

[49] SERNANP, Expediente Técnico: Establecimiento de la Reserva Nacional Sistema de Islas, Islotes y Puntas Guaneras, (2009).

[50] D.C. Duffy, C. Hays, M.A. Plenge, The conservation status of Peruvian seabirds, in: Status and Conservation of the World's Seabirds, 1984.

[51] W. Cai, S. Borlace, M. Lengaigne, P. van Rensch, M. Collins, G. Vecchi, A. Timmermann, A. Santoso, M.J. McPhaden, L. Wu, M.H. England, G. Wang, E. Guilyardi, F.-F. Jin, Increasing frequency of extreme El Niño events due to greenhouse warming, Nature Climate Change. 4 (2014) 111-116. https://doi.org/10.1038/nclimate2100.

[52] República del Perú, Decreto Supremo que Aprueba el Establecimiento de la Reserva Nacional Sistema de Islas, Islotes y Puntas Guaneras, 2009.

[53] República del Perú, Ley de Áreas Naturales Protegidas, 1997. http://www.minam.gob.pe/wpcontent/uploads/2017/04/Ley-N²-26834.pdf (accessed March 21, 2019).

[54] AGRORURAL, Guía básica de actividades para el personal guardaislas de agrorural, Programa de Desarrollo Productivo Agrario Rural, Ministerio de Agricultura, Lima, Perú, 2013.

[55] Fonseca, Camargo y Asociados, CONFE Auditores, Auditoría de estados financieros del Proyecto "Fortalecimiento de la Gestión Sostenible de la ReservaNacional Sistema de Islas, Islotes y Puntas Guaneras", financiado por Global Environment Facility -GEF, através del Banco Internacional de Reconstrucción y Fomento -BIRF Convenio de Donación NTF015896 por el período comprendido

Laínez del Pozo, D. and Peter J.S. Jones (in press) Governance analysis of two historical MPAs in northern Peru: Isla Lobos de Tierra and Isla Lobos de Afuera. Marine Policy 104096 https://doi.org/10.1016/j.marpol.2020.104096 One of 20 papers in a special section of 28 case studies on MPA Governance 
del 01 de enero al 31 dediciembre del 2017, World Bank, 2018.

http://documentos.bancomundial.org/curated/es/450511533587868961/pdf/PER-P129647-

TF15896-Proyecto-con-PROFONANPE-EEFF-del-1-de-Enero-al-31-de-Diciembre-de-2017.pdf (accessed August 11, 2019).

[56] SERNANP, Plan Maestro de la Reserva Nacional Sistema de Islas, Islotes y Puntas Guaneras 2016 - 2020, (2016).

[57] J. Quiñones, I. García-Godos, M. Llapapasca, F.V. Ordt, E. Paredes, The Black Sea Turtle (Chelonia mydas agassizii) at Lobos de Tierra Island, Northern Peru: High Densities in Small Areas, South American Journal of Herpetology. 10 (2015) 178-186. https://doi.org/10.2994/SAJH-D-1400040.1.

[58] J. Figueroa, L. Timaná, S. García, J. Ordoñez, V. Chávez, C. Gutiérrez, Estado del Piquero de Pico Naranja Sula granti en Perú (1980-2017), Cotinga 41. (2019) 2-11.

[59] M. Carrere, Crisis IMARPE: las posibilidades que se abren tras el mayor escándalo pesquero de los últimos años, Mongabay Latam. (2020). https://es.mongabay.com/2020/02/peru-crisis-enimarpe-oportunidades-tras-el-decreto-de-urgencia/ (accessed February 26, 2020).

[60] M.P. Pimbert, J.N. Pretty, Parks, People and Professionals: Putting 'Participation' into Protected Area Management, UNRISD, IIED, WWF, Geneva, 1995.

https://sergiorosendo.pbworks.com/f/Pimbert+and+Pretty+1995+Participation+and+protected+are a+management.pdf (accessed September 16, 2019).

[61] J. Figueroa, Las aves de la isla Lobos de Tierra, Perú: revisión bibliográfica y nuevos registros (1684-2011), Revista Brasileira de Ornitologia. 21 (2013) 58-74. 